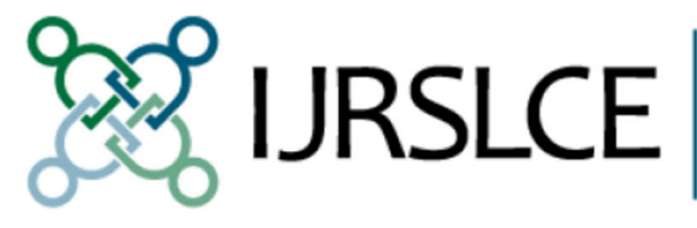

International Journal

for Research on

Service-Learning \&

Community Engagement

Using Active-Learning Strategies to Increase Pre-Service Teachers' Efficacy in a Service-Learning Course

\author{
Larry P. Nelson \\ Mary Lynn Crow
}

Kathleen Tice

This article was originally published at:

https://journals.sfu.ca/iarslce/index.php/journal/article/view/106/70

Recommended Citation

Nelson, L. P., Crow, M. L., \& Tice, K. (2015). Using active-learning strategies to increase preservice teachers' efficacy in a service-learning course. International Journal of Research on Service-Learning and Community Engagement, 3(1), Article 19. 


\title{
Using Active-Learning Strategies to Increase Pre-Service Teachers' Efficacy in a Service-Learning Course
}

\author{
Larry P. Nelson \\ Mary Lynn Crow \\ Kathleen Tice \\ University of Texas at Arlington
}

\begin{abstract}
Improving pre-service teachers' ability to recognize work-related problems and apply effective strategies and solutions to fundamental challenges in the field is at the crux of an effective college preparation. Although there is evidence that service-learning experiences within a teacher education course can have powerful effects on student learning, what is being done during the lecture portion of a course to improve the impact of service-learning practices goes largely unexamined. This study investigated whether a contextually developed set of active-learning strategies in the lecture part of a service-learning course improved pre-service teachers' efficacy. Findings showed significant improvement within personal teaching efficacy constructs as a result of experiencing the active-learning sequence. Academic tracking of students showed that those pursuing a Bachelor of Arts in physical education teacher education benefitted significantly more from the active-learning experience than those pursuing a Bachelor of Science in athletic training. This article describes how the active-learning sequence emerged as a preferred method of instruction by instructors and students, and how these strategies were useful in problematizing teaching situations and engaging students with course content.
\end{abstract}

Keywords: service-learning, teacher efficacy, active-learning, physical education teacher education

In 2008, the Council for Industry and Higher Education created the International Employer Barometer, which surveyed 233 large multinational and small companies across a range of social and technical skill areas (Archer \& Davison, 2008). Findings showed that skills such as communication and teamwork ability by college graduates were the most important and sought after aptitudes by employers. In addition, three out of four employers ranked analysis and decision-making skills as the most important skills for the future. Not surprisingly, the National Research Council (2012)-along with university centers and employers - has called on higher education faculty to not only adopt more active methods of instruction that engage students directly with course content, but also provide strategies to help students develop critical thinking skills and solve everyday problems. Even though the practice and development of these skills have received overwhelming support, studies have shown that $65 \%$ to $80 \%$ of university instructors spend their class time lecturing to a passive student audience and devoting little or no attention to cultivating group-development, active-learning, or problem-solving skills (Blackburn, Pellino, Boberg, \& O'Connell, 1980; Chickering \& Gamson, 1991; Panek, 2005; Smith \& Van Doren, 2004). Servicelearning has the potential to address the shortcomings of higher education by providing university students with opportunities to collaborate with one another and with partners in the community, apply knowledge and skills, and think critically about solving problems. Well-designed service-learning experiences can also prepare students for real-life situations they might encounter in the workplace. 
For university students who are going to be working as teachers and coaches in schools, a critical part of their professional development is to ensure that they feel like they can engage in teaching situations effectively and be successful. Previous research has demonstrated that service-learning can foster efficacy beliefs among pre-service teachers (Nelson, Tice, \& Theriot, 2008; Tice \& Nelson, 2013, 2015). The present study builds upon these findings by examining whether active-learning strategies can enhance the gains in efficacy associated with service-learning by expanding students' preparation for their servicelearning experience.

\section{Service-Learning in Teacher Education}

In 1996, the National Commission on Teaching and America's Future issued a call to strengthen teacher preparation programs through a variety of reforms, including deeper candidate participation in clinical experiences. Since that time, teacher education programs throughout the U.S. have made "significant headway" in incorporating the reforms, "creating stronger clinical practice, strengthening coursework around critical areas ... and connecting this coursework directly to practice in much more extensive practice settings" (Darling-Hammond, 2010, p. 36). Many teacher preparation programs now require clinical experiences that are directly tied to coursework and that engage pre-service teachers in authentic teaching and learning collaborations, partnerships, and mentoring programs (Darling-Hammond, 2000; Huang, 2006).

One strategy for linking teacher education coursework with field experiences is service-learning. Furco (2001) defined service-learning as "a teaching strategy that enhances students' learning of academic content by engaging them in authentic activities in which they apply the content of the course to address identified needs in the local and broader community" (p. 67). Teacher education experts have argued that service-learning has the potential to expose pre-service teachers to situations that could occur on the job, uncover obscure assumptions that might interfere with their ability to effectively teach all students, and engage them in solving real-world problems with professional and experienced consultants (Baldwin, Buchanan, \& Rudisill, 2007). In effect, service-learning creates an opportunity for students and faculty to question, analyze, and process timely challenges occurring in the field in a collaborative setting that supports personal, social, and academic growth.

Although the practice of service-learning in teacher education is widespread, the number of faculty who understand how to use the pedagogy skillfully is relatively small (Anderson \& Erickson, 2003; Furco \& Ammon, 2000; Potthoff, Dinsmore, Stirtz, Walsh, Ziebarth, \& Eifler 2000). This is due in part to the limited empirical basis for service-learning best practices as well as to obstacles that may preclude the implementation of the strategy. For example, one of the most common hurdles university faculty face is a lack of time to plan and implement service-learning experiences that require wide-ranging leadership and detailed coordination with community partners (Butin, 2003; Hondagneu-Sotelo \& Raskoff, 1994).

\section{Teacher Efficacy}

According to Bandura (1977), self-efficacy comprises "beliefs in one's capability to organize and execute the course of action required to produce given attainments" (p. 3). He argued that four external experiences or self-perceptions contribute to the development of self-efficacy: mastery experiences, modeling or vicarious experiences, social persuasion, and emotions or physiological factors such as fatigue, fear, and pain. Teaching efficacy refers to the teacher's belief in his or her ability to influence learning, even among students "who may be difficult or unmotivated" (Guskey \& Passaro, 1994, p. 4). Researchers typically distinguish between two dimensions of teaching efficacy: personal teaching efficacy, the belief that individual teachers can be effective in reaching personal teaching goals and outcomes regardless of educational obstacles, and general teacher efficacy, the belief that collectively teachers (and the education system in general) can be effective with enhancing student learning and reaching educational outcomes (Armor, Conroy-Oseguera, Cox, King, McDonnell, Pascal, Pauly, \& Zellman, 1976). 
Henson, Kogan, and Vacha-Haase (2001) concluded that a strong sense of efficacy is perhaps "one of the best documented attributes of effective teaching" (p. 404). Highly efficacious teachers have students who learn more and are more motivated (Ashton, 1984; Shahid \& Thompson, 2001; Tschannen-Moran, Woolfolk-Hoy, \& Hoy, 1998), demonstrate higher levels of enthusiasm and are more apt to implement instructional innovations (Ghaith \& Yaghi, 1997; Woolfolk-Hoy \& Davis, 2006), and are more likely to remain in the profession (Henson, 2001). Schwarzer and Hallum (2008) found that low general selfefficacy led to job stress and burnout, especially for teachers under the age of 40. Based upon their findings, they recommended that "strengthening teachers' optimistic self-beliefs along with improved teaching skills should be a preventative measure to avoid this downward spiral" (p. 169).

\section{Service-Learning and Teacher Efficacy Research}

A number of studies have shown the positive effects of service-learning participation on pre-service teachers' self-efficacy. For example, teaching candidates in a literacy course with a service-learning component in which students applied literacy teaching skills at an elementary school for low-performing and diverse students made greater gains in self-efficacy and were more apt to implement course content than their counterparts in the same course (Wasserman, 2009). Drawing on Bandura (1977), Wasserman (2009) attributed these differences to the greater mastery of learning experienced by service-learning students. Cone (2009) conducted a similar study in which teacher candidates in one course participated in service-learning (leading inquiry-based science lessons for low-income minority elementary students in a community center), while candidates in a parallel course implemented inquiry-based science lessons with their peers. Candidates who participated in the service-learning experience made significantly greater gains in their sense of efficacy in providing equitable science teaching than those students who did not. Kirtman (2008) found similar increases in teacher candidates' self-efficacy as it related to their understanding and confidence to teach mathematics, and Todd and Brinkman (2008) reported the same type of self-efficacy gains in teacher candidates' teaching of social studies.

While service-learning is associated with increased teaching efficacy among pre-service teachers, contextual variables surrounding the service-learning experience have been found to moderate its effects. For example, in a study of pre-service teachers from nine teacher education programs, Root, Callahan, and Sepanski (2002) found gains in teaching efficacy only among candidates who reported receiving support for their efforts, including adequate training for tasks and assistance from either an instructor or a placement supervisor in adjusting to the service-learning experience. Increased teaching efficacy was also linked to having received previous instruction in service-learning as a teaching method and having responsibility for implementing service-learning during a practicum or student teaching.

Undoubtedly, service-learning is a promising pedagogy for effective field experiences in teacher education. However, poorly designed and/or inappropriately managed service-learning experiences characterized by a lack of planning and preparation, insufficient guidance and direction from faculty, or non-supportive community collaborations can all undermine candidates' feelings of efficacy (Tice \& Nelson, 2015). These issues point to the importance of preparing pre-service teachers for service-learning projects so that they are more apt to be successful and make gains in self-efficacy (Abrami, Bernard, Borokhovski, Wade, Surkes, Tamim, \& Zhang, 2008).

In this study, we hypothesized that an active-learning sequence focused on engaging pre-service teachers with problem-based learning linked to a required service-learning component would more effectively cultivate a sense of teacher efficacy than traditional classroom instruction. We expected that the experience of addressing discernible problems, while learning about strategies and solutions for addressing them, would help students develop the higher order thinking skills necessary to interpret, analyze, and address similar problems in the classroom. Research questions included: (1) Does a strategically developed active-learning sequence improve pre-service teachers' sense of efficacy when they engage in service-learning? (2) Does an active-learning sequence differentially affect gains in the efficacy of students with different academic majors? 


\section{Methods}

\section{Participants}

Participants in this study $(\mathrm{N}=100)$ comprised student teachers from a large diverse urban research university who were enrolled in a secondary physical education teaching methods course during the fall 2010, spring 2011, fall 2011, and spring 2012 semesters. These students were pursuing either a Bachelor of Arts in physical education teacher education $(\mathrm{N}=77)$ or a Bachelor of Science in athletic training with all-level teacher certification $(\mathrm{N}=23)$. The non-core coursework for each program differs. Specifically, BA students spend numerous hours observing and teaching in the public schools and have multiple opportunities to gain teaching experience and practice public speaking prior to entering the course. In contrast, students pursuing a BS in athletic training typically gain more experience diagnosing problems and designing actions for success.

\section{Course Attributes}

The methods courses offered during the fall 2010 and spring 2011 semesters were lecture-style courses that relied on presentation of material using PowerPoint slides and multiple-choice exams based on a popular physical education methods textbook. In the methods courses offered during the fall 2011 and spring 2012 semesters, the slides, exams, and lecture format were largely replaced by an active-learning intervention comprising nine 50-minute experiences including role-plays, case studies, and small-group discussion designed to promote problem-solving and critical thinking skills that related to students' service-learning. The effectiveness of these three active-learning strategies in developing higher order thinking among students is widely documented in the literature (Bain, 2004; Barclay, Cross, \& Major, 2005; Barnes, Christensen, \& Hansen, 1994; Bean, 2011; Brookfield, 1987; Dewey, 1944; Honan \& Rule, 2002; Mitchell, 2004; Moore, 2014; Paul \& Elder, 2009; Youngblood \& Beitz, 2001). In each activelearning experience, students were placed in small groups, given case studies that included problematic situations, and directed to analyze and discuss the cases, then role-play possible solutions. The case studies were based on scenarios the students might have realistically encountered during the servicelearning experience (and in future teaching) and as such conformed to Bean's (2011) definition of a good case: "Good cases generally tell a real or believable story, raise thought-provoking issues based on conflict, lack an obvious or clear-cut answer, and demand a decision reached through critical thinking and analysis" (p. 159). The cases for the course were not contrived but were based upon actual challenging situations that had taken place during previous semesters of the service-learning projects.

After reading and discussing the original cases, students were asked to write (individually and as a group) what they wanted to accomplish through the role-plays, including the exact words and techniques to be used. Moore (2014) argued that "role-playing unfamiliar or disorienting perspectives or imaging 'what if' situations makes an excellent critical thinking exercise" (p. 156). Role-plays were repeated so that multiple pre-service teachers could try out their own solutions and other students could see different approaches to solving problems. The post-role-play discussions were pre-planned, detailed, and in-depth, and explored how the classmates and professors reacted to the differing solutions to the challenges presented (see Appendix for an example of a role-play used in the study).

In conjunction with the methods course, all students participated in the same service-learning experience each semester. The majority of students (67\%) either coached or co-coached in an after-school soccer program that required 60 to 70 hours of directly instructing and managing middle school students at practices (after school) and games on Saturdays. The remaining students (33\%) designed, implemented, and instructed a volunteer service-learning project with secondary level students in the public schools (e.g., athletic training events, fitness hiking competitions, and fitness testing events).

\section{Instruments}

To measure their sense of efficacy, pre-service teachers in this study responded to the Teacher Efficacy Scale (Tschannen-Moran \& Woolfolk-Hoy, 2001; Woolfolk \& Hoy, 1990) at the beginning and end of each semester of the course. This scale is designed to measure personal teaching efficacy (PTE) and 
general teacher efficacy (GTE). Examples of statements that respondents rate on the PTE scale include: (1) "When a student does better than usual, many times it is because I exert a little extra effort"; (2) "If one of my students couldn't do a class assignment, I would be able to accurately assess whether the assignment was at the correct level of difficulty"; and (3) "My teacher training program and/or experience has given me the necessary skills to be an effective teacher." Examples of statements on the GTE scale include: (1) "The hours in my class have little influence on students compared to the influence of their home environment"; (2) "Teachers are not a very powerful influence on student achievement when all factors are considered"; and (3) "Even a teacher with good teaching abilities may not reach many students" (all reverse scored).

A confirmatory factor analysis (using squared multiple correlations on the diagonal and the PA2 extraction option in SPSS) was computed to substantiate the two dimensions of the teacher efficacy instrument. The two factors were uncorrelated $(r=.017)$ and accounted for $37 \%$ of the total variance. These findings are similar to other validity investigations of the Teacher Efficacy Scale (Denzine, Cooney, \& McKenzie, 2005). A Cronbach's $\alpha$ coefficient of .79 was computed for scores on 12 PTE items, while Cronbach's $\alpha$ coefficient of .72 was computed for eight GTE items, indicating high internal reliability for both dimensions of efficacy. Two items did not load at .40 or higher on either scale and were discarded from analysis.

A quasi-experimental nonequivalent groups design was applied using a repeated measures multivariate analysis to test for differences in PTE and GTE due to time (pre-survey vs. post-survey); experimental (active-learning) vs. control (traditional) condition; type of service-learning experience associated with the course; and students' academic track. In order to parse the effects of differences between scores on the pre-test, an ANCOVA statistic was applied to the analysis when testing for between group variances (i.e., using pre-test scores as a covariate).

A naturalistic approach (Lincoln \& Guba, 1985) was also used to collect data in the form of studentcentered focus groups, individual student journal reflections, and a final written self-evaluation. Focus groups with a representative sample of students were conducted each semester by an independent representative from the provost's office at three separate times spaced evenly throughout the semester. Questions concerned the extent to which students were actively engaged in the learning process. Individual journals were used to record students' personal feelings about their experiences during both coursework and the service-learning component. The self-evaluation was an open-ended culminating reflection about what students liked or disliked in the course, how they changed as a result of the course, and how they would assess their own performance and the extent to which they took advantage of teaching and learning opportunities.

\section{Findings}

Results showed a significant main effect for time, with the post-test scores being higher than the pre-test scores in both PTE and GTE measures for the control and experimental groups (see Table 1). In the case of GTE, there were no significant differences, $\mathrm{F}(1,98)=.000, p=.985$, between control and experimental group scores (see Figure 1). However, in the case of PTE, there was a significant difference, $\mathrm{F}(1,98)=8.741, p=.004$, between conditions where the experimental group reported significantly higher mean scores than the control group (see Figure 2). Moreover, when we ran a two-way analysis (removing the variable for condition [i.e., control vs. experimental]), we found that the academic track of students (physical education teacher education students vs. athletic training students) had significant effects, F $(1,98)=6.373, p=.013$, within the Personal Teaching Efficacy construct (see Table 2). Both academic groups made significant gains in PTE; however, physical education majors (who began with lower pre-test scores) benefited significantly more from the experience than the athletic training education majors (see Figure 3). Results showed no significant differences in PTE or GTE due to the type of service-learning experience. 
Table 1. Teacher Efficacy Scores by Time and Condition

\begin{tabular}{|c|c|c|c|c|c|c|c|c|}
\hline \multirow[b]{2}{*}{ Scale } & \multirow[b]{2}{*}{ Condition } & \multirow[b]{2}{*}{$\mathbf{N}$} & \multicolumn{2}{|c|}{ Pre-Test } & \multicolumn{2}{|c|}{ Post-Test } & \multirow{2}{*}{$\begin{array}{c}\text { Time } \\
\text { (Pre-Post) } \\
(\text { F) } \\
\end{array}$} & \multirow{2}{*}{$\begin{array}{c}\text { Time * } \\
\text { Condition } \\
(F)\end{array}$} \\
\hline & & & Mean & $S D$ & Mean & $S D$ & & \\
\hline \multirow[t]{3}{*}{ PTE } & Control & 49 & 51.43 & 6.63 & 52.94 & 6.72 & & \\
\hline & Experiment & 51 & 53.14 & 6.03 & 57.35 & 5.70 & & \\
\hline & Total & 100 & 52.30 & 6.36 & 55.19 & 6.58 & $39.151^{*}$ & $8.741^{*}$ \\
\hline \multirow[t]{3}{*}{ GTE } & Control & 49 & 30.88 & 4.89 & 32.35 & 4.40 & & \\
\hline & Experiment & 51 & 32.43 & 6.04 & 33.92 & 7.70 & & \\
\hline & Total & 100 & 31.67 & 5.54 & 33.15 & 6.33 & $7.653 *$ & .000 \\
\hline
\end{tabular}

* Significant at the $\mathrm{p}<.05$ level

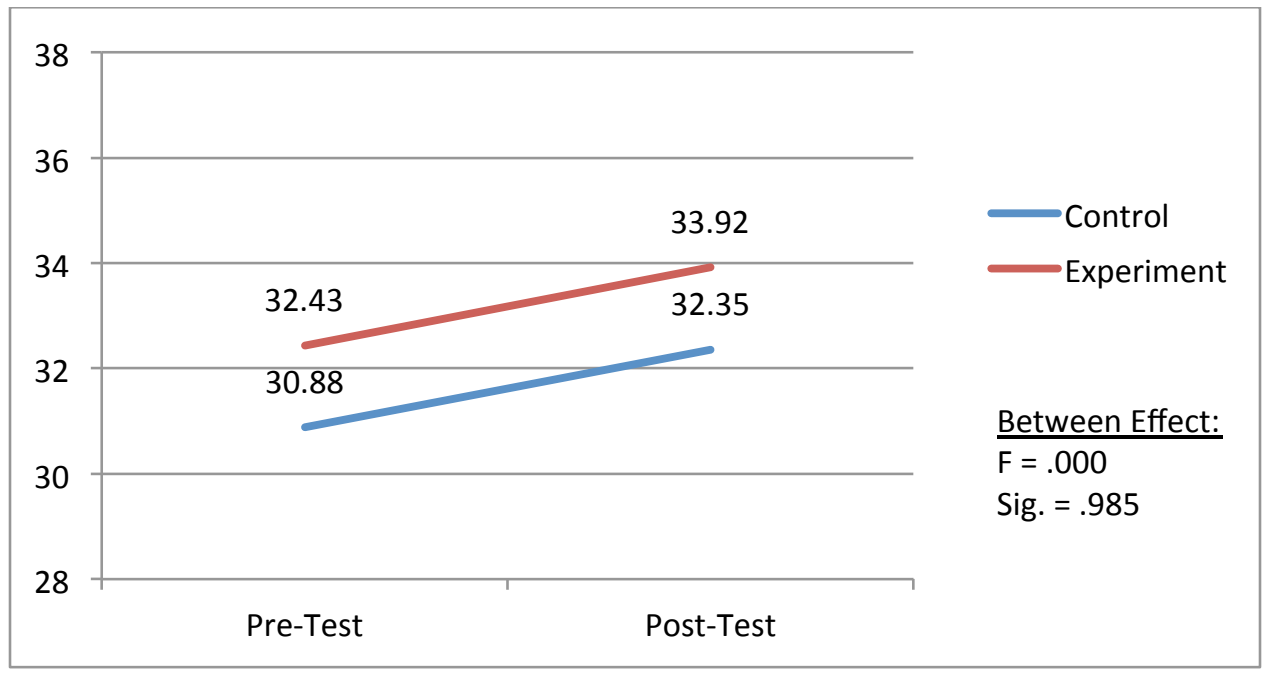

Figure 1. General teacher efficacy gains by condition. 


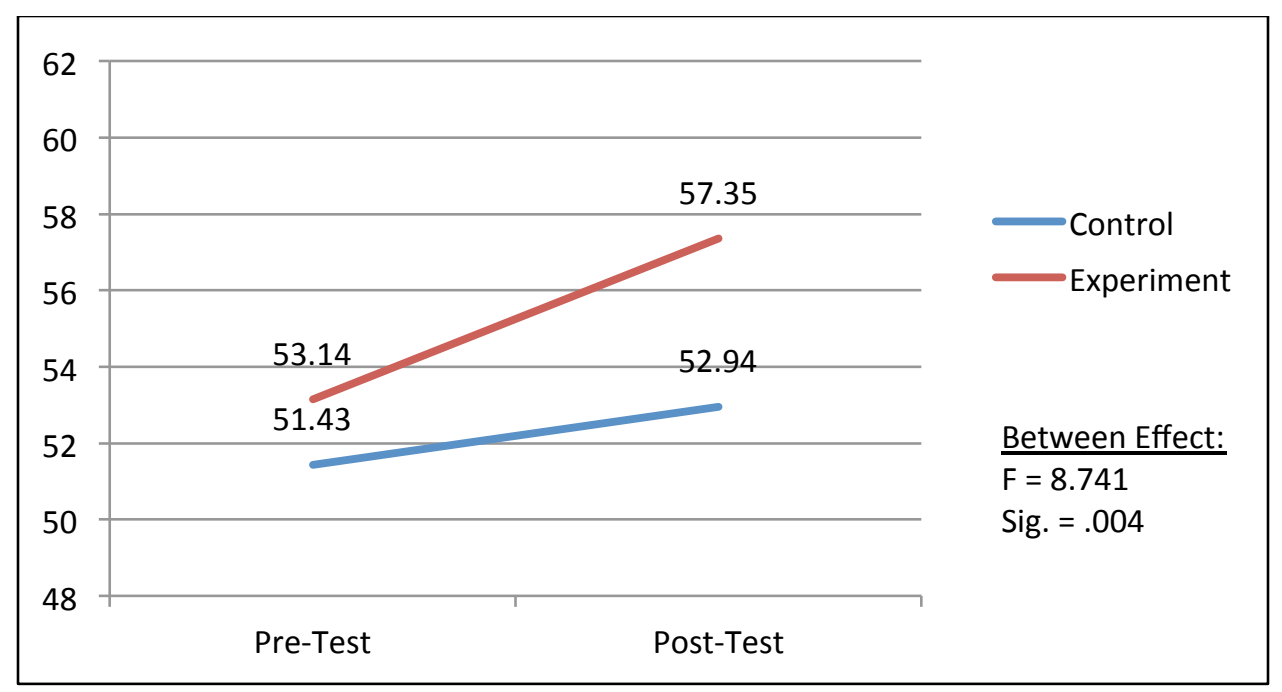

Figure 2. Personal teaching efficacy gains by condition.

Table 2. Teacher Efficacy Scores by Academic Track

\begin{tabular}{llccccccc}
\hline & \multicolumn{4}{c}{ Pre-Test } & \multicolumn{2}{c}{ Post-Test } & Time & Time * \\
Scale & Track & $\mathrm{N}$ & Mean & SD & Mean & SD & $($ F $)$ & $(F)$ \\
\hline PTE & BA PE & 77 & 51.34 & 5.68 & 55.03 & 6.76 & & \\
& BS AT & 23 & 54.34 & 7.27 & 55.53 & 6.25 & & \\
& Total & 100 & 52.30 & 6.36 & 55.19 & 6.58 & $24.20^{*}$ & $6.37^{*}$ \\
\hline \multirow{2}{*}{ GTE } & BA PE & 77 & 31.87 & 5.24 & 33.03 & 5.70 & & \\
& BS AT & 23 & 31.25 & 6.18 & 33.41 & 7.57 & & \\
& Total & 100 & 31.67 & 5.54 & 33.15 & 6.33 & $8.441^{*}$ & .758 \\
\hline
\end{tabular}

Note. BA PE $=$ Bachelor of Arts in physical education teacher education; BS AT= Bachelor of Science in athletic training

$*$ Significant at the $\mathrm{p}<.05$ level 

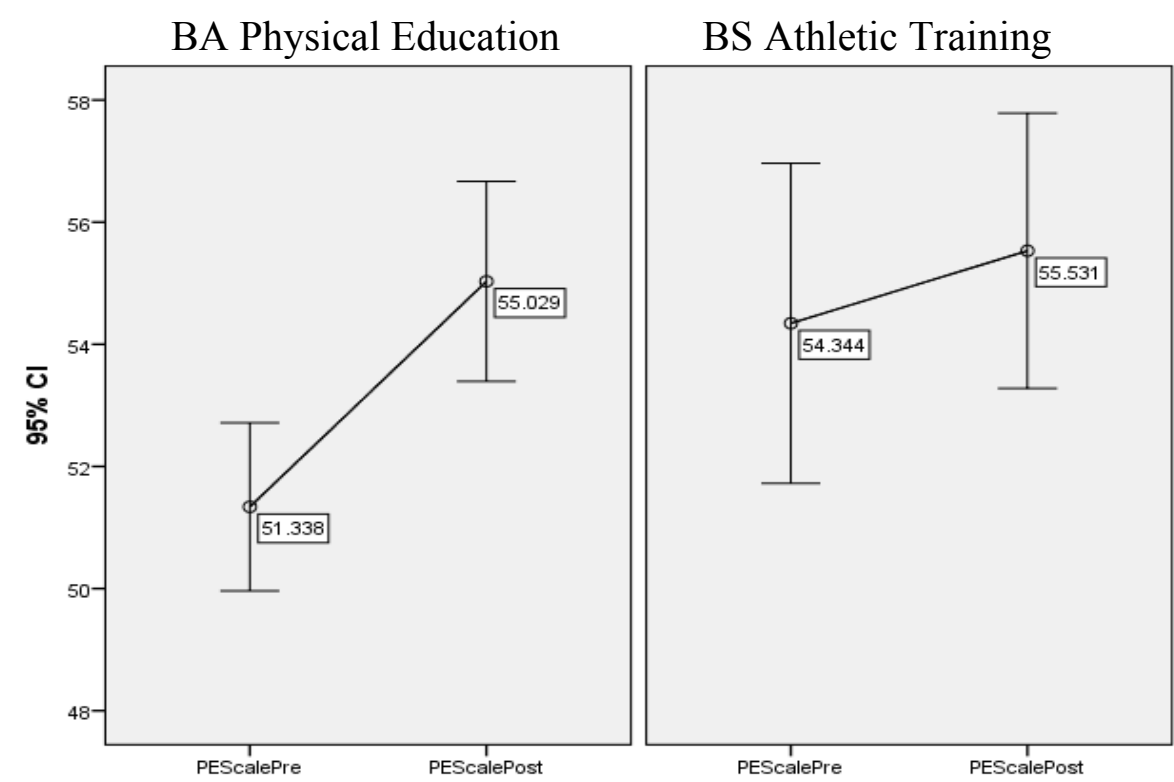

Figure 3. Personal teaching efficacy gains by kinesiology degree program.

We recorded, transcribed, and analyzed qualitative data from each source, noting all salient and recurring units of meaning relevant to the quantitative findings from the active-learning intervention. Qualitative findings yielded support for the active-learning strategies used in the study, while delineating more clearly ways in which the active-learning experiences fostered gains in efficacy. One emergent theme concerned the ways in which the active-learning scenarios fostered self-assessment and the generation of alternative solutions for handling challenging situations. As one pre-service teacher noted:

At first I was a little apprehensive about the role-play vignettes but they did make me think about how I would react to those kinds of circumstances and if my first instincts would have been the right thing to do. I have realized I have a weakness with unfairness, wrong behavior, and confrontation.

One pre-service teacher described the ways in which the active-learning scenarios offered insights into the varying responses to challenging classroom problems and the opportunity to practice responding in a safe setting:

The class discussions really opened my eyes to different ways of handling tough situations that can occur in a school setting. I realize there are many ways of addressing students and that I have a huge weakness with dealing with hostile students. It was nice to get a chance to run through these scenarios in a lab-like setting because I have a much better idea how to manage students who have little to lose.

A second theme that surfaced in the qualitative data involved the degree to which pre-service teachers gained feedback from class members:

The group activities showed me that I need to do a better job pausing for a moment and really think through how I go about reaching my goal. Typically, I would just command a behavior and tell my players what to do. I realize now that I need to focus more on the goal and see the situation 
as an opportunity to teach a lesson and not allow my knee jerk emotions and frustrations to overtake the goal along the way.

Another pre-service teacher found that observing other class members was the most beneficial aspect of the active-learning scenarios:

Watching others handle tough situations was the most useful part. I remember several of us saying to ourselves, Oh, I would have never thought to say that or handle things that way... or that was handled well. I remember complimenting after class one day, telling him I enjoyed the way he handled that situation, how professional he was about it, and how it got me thinking about how I might do things differently.

A third theme focused explicitly on the link between the experience of participating in the activelearning scenarios and self-efficacy:

The role-play activities were similar to some of the issues I encountered during coaching. Figuring out solutions to likely problems and learning new tips for dealing with these kinds of issues really improved my ability to handle these types of situations when they happened. I have more confidence that I can handle difficult situations when they arise.

Comments of other pre-service teachers centered on the benefits of experiencing situations that were similar to those they would encounter in the field:

Role-play gets you closer to the real deal rather than just listening to someone tell you how to do it. It was never boring; I was always eager to see how different people would respond. I looked forward to seeing all the different techniques. I feel like it forces you to respond quickly while thinking critically, so you have to be on your toes in class. You know you are going to have to respond so you can't just sit back in class, watch others, and act like you are paying attention.

\section{Discussion}

\section{Why Efficacy Gains Were Made in the Service-Learning Course}

The purpose of this study was to explore the impact of active-learning strategies in a physical education methods course that included service-learning on pre-service teachers' sense of teaching efficacy. As stated previously, results showed that both the control and experimental groups experienced substantial gains in personal teaching efficacy and general teacher efficacy over time. The gains in efficacy beliefs indicate that classwork on effective practices for teaching physical education in combination with servicelearning contributed to pre-service teachers' confidence in their ability and the ability of educators in general to positively impact student learning.

These findings can be interpreted in light of the sources of efficacy beliefs identified by Bandura (1977, 1986, 2001). It seems likely that the course and the service-learning component provided preservice teachers with mastery experiences, which Bandura noted are the most influential sources of efficacy beliefs. We argue that pre-service teachers were unsure of their ability to positively impact service-learning, but as they participated in the course and engaged in projects, they received support from teams of class members as well as the instructors of the course who worked closely with community partners. The instructors also offered support by presenting content during class meetings and by providing opportunities for reflection and discussion once the projects were underway. Finally, preservice teachers were consistently able to observe their classmates engaging in teaching on a regular basis and succeeding, which provided vicarious sources of efficacy beliefs.

The results showed that the active-learning strategies used in the experimental condition helped preservice teachers feel more confident in their own ability to promote student learning than others taught 
using traditional strategies. By planning how to handle very specific situations, role-playing these techniques, and receiving feedback from peers and professors afterward, students had a chance to learn that they could individually and effectively face school and classroom challenges. Rarely do beginning teachers get a trial "run through" experience that encourages mistakes without any real consequences for students. Opportunities afforded by the role-plays included the ability to take a timeout from action, consider multiple angles and solutions, and rethink how to approach a particular situation.

The failure to find greater gains in general teacher efficacy may have been due to the case studies, role-plays, and discussions focusing more on individual solutions and accomplishments than on solutions applicable to the physical education profession as a whole. The lower level of gains in GTE (as compared to the greater PTE gains) also could be attributed to the negative perception of what teachers in general are able to achieve. Crow and Pant (2015) found that 2,014 graduate education students, who were at the time teaching full-time in the public schools, viewed the profession much more negatively than did graduate education students at the same university in 1988 .

The course under study was a secondary physical education teaching methods course in which the service-learning component was primarily linked to physical education and coaching field experiences. Therefore, it is not surprising that the findings showed that the physical education majors benefited more from the course than athletic training majors. For example, the intensity of the assigned field experiences (in relation to course content) was typically very different for both sets of students. This has significant curricular and degree program implications. These findings suggest two solutions: (1) The course instructor needs to create a more equivalent and relevant active-learning sequence akin to "athletic training" service-learning projects, or (2) advocate that the course be designed for physical education teacher education majors only.

\section{Limitations of the Study}

A primary limitation of the study was the absence of a true experimental or quasi-experimental design in which the independent variable of the active-learning varied between sections of the same course during the same semester with the same instructor. Additionally, the study did not allow us to examine separately the effects of the active-learning sequence and service-learning.

\section{Conclusions}

This study sought to measure the effects of substituting active-learning for traditional instruction in a physical education teaching methods course with a service-learning component on pre-service teachers' self-efficacy. Results showed that the methods coursework and the opportunity to apply it through service-learning were associated with significant gains over time in both personal teaching efficacy and general teacher efficacy regardless of condition. However, pre-service teachers who experienced the active-learning sequence expressed greater confidence in their ability to face challenging teaching situations and find effective solutions (personal teaching efficacy) than those receiving traditional instruction-results which the qualitative findings suggest are attributable to opportunities to engage in problem-solving, observe, and receive feedback from others.

As concerns about producing effective teachers continue to grow, teacher education programs need to be acutely aware of how coursework, instruction, and training contribute to the development of preservice teachers' confidence in their ability to help students learn. The instructors in this study tried to do this by incorporating active-learning strategies into a teaching methods course in conjunction with an already well-established service-learning component. While the combination of service-learning and methods coursework yielded increased confidence about teaching, it was the connection between classbased preparation for responding to dilemmas that might be encountered in service-learning (and the opportunity to apply that learning through service-learning) that led to the greatest gains in personal teaching efficacy. 


\section{Appendix}

\section{Role-Play Example}

Directions: Students read vignette and take a few minutes to write down key points about how to handle the situation and accomplish a reasonable outcome. Students are then paired up so that each takes a role and works through each key point (Note: Instructor can stop in the middle of this phase to check in with how student or teacher now feels in that role). Facilitator then calls up two people from the class to play the role of the student and the teacher (Note: The teacher role can have 1 or 2 helpers behind them to consult with if they need help or get stuck - i.e., whisper ideas into their ear...). Once this process has been worked through adequately, the facilitator leads a discussion of what worked well and what didn't work so well, and calls up new students to play each role again. Students take notes on what worked well and examine how different approaches and styles might work best for their particular temperament, and if they need to develop any traits to become more successful in the future handling these types of situations. Finally, the instructor summarizes, reemphasizes, and shares the talking points brought up throughout the process.

\section{Example Role-Play: "Bullying"}

You are a substitute teacher and have been called in this morning to cover Mr. Daniels PE classes for the rest of the semester (about 3 weeks) at Eagle Lake High School. There were no lesson plans left for you. Fifth period rolls around where juniors and seniors enter the gym for a class called "Team-Sports." They tell you they have been playing a flag-football unit and a few students immediately enter the equipment closet and pull out the necessary equipment. A senior named Dominick divides up teams and runs the class very efficiently leaving you very little time and opportunity to manage and/or control anything. The game begins and Dominick exhibits extremely aggressive behavior towards the opposing team - hitting students hard and tripping and tackling them to the ground violently. He is also abusive to his own teammates yelling at them when they make a mistake and blame them for anything that goes wrong on their team. It is obvious the students are afraid of him and will do anything to try and just appease him and/or stay out of his way. You ask Dominick to speak with you in the office. What is your next move?

Results:

- STAY CALM ALWAYS! Have confidence \& use good eye-contact (and even ask for eye-contact back if necessary to emphasize the seriousness of the situation). Acknowledge his motivation level and skilled level of play (being punitive may make matters worse... at least until you get to know him better). Don't engage him emotionally/confrontationally, but be assertive using "I" statements like "Here's what I think... Here's what I want you to do...".

- Show respect and empathy by asking questions and trying to understand his perspective and situation. Students need to see that you care and have passion for them and their education. If necessary try to get "buy in" by asking what he would like to do and negotiate alternative roles/responsibilities... Have him do another task (i.e. referee, assistant coach, statistician, etc.). Constant caring on a consistent basis.

- Video the behavior and have him watch it with you in conference... Help him understand that the consequences of his actions could lead to injury of others (physical and/or psychological). This could also lead to bigger problems (civil/legal action by other students' parents, suspension from school, etc.).

- Remind him of the Golden Rule- "Do unto others as you would have them do unto you."

- Set expectations and get agreement. Give him simple goals to work on with 1 or 2 outcomes/cues. Also, go over these expectations routinely (with him and the class) and post these social responsibility rules around the classroom/gym (See Don Hellison's work on promoting social 
responsibility through physical activity):

http://davidpetersoneportfolio.weebly.com/uploads/1/0/5/4/10549140/pe workshop.pdf

http://www.pecentral.org/climate/january99article.html

- Make it about fun for everyone... Team-work! Try to make health connections for improving his behavior.

- Modify the flag-football rules/equipment of the game to minimize opportunities for inappropriate behavior and harm.

- If need be, buy some time to ask other teachers/colleagues' advice in order to be confident in your approach/strategy/goals. Present alternative (better fitting) opportunities (e.g., Football Team)... Perhaps you can request he get moved to athletics instead of PE as a "better fit" for him.

\section{Author Note}

Larry P. Nelson, Department of Kinesiology, University of Texas at Arlington; Mary Lynn Crow, Department of Curriculum and Instruction, University of Texas at Arlington; Kathleen Tice, Department of Curriculum and Instruction, University of Texas at Arlington.

This study was supported by a grant from the University of Texas at Arlington's Provost Office (Quality Enhancement Program - Phase II for Research). Special thanks go to David Silva (Vice Provost for Academic Affairs) and Araya Maurice (QEP Assessment Director) for their assistance.

\section{Correspondence}

Correspondence regarding this article should be addressed to Larry P. Nelson, Department of Kinesiology, 500 W. Nedderman Drive, University of Texas at Arlington, Arlington, TX, 76019-0259. E-mail: 1nelson@uta.edu

\section{References}

Abrami, P. C., Bernard, R. M., Borokhovski, E., Wade, A., Surkes, M. A., Tamim, R., \& Zhang, D. (2008). Instructional interventions affecting critical thinking skills and dispositions: A stage 1 meta-analysis. Review of Educational Research, 78(4), p. 1102-1134. Retrieved from http://rer.sagepub.com/content/78/4/1102.short

Anderson, J., \& Callahan, J. (2005). The institutionalization of service-learning in preservice teacher education. In S. Root, J. Callahan, \& S. Billig (Eds.), Advances in servicelearning: Improving service-learning practice (pp. 17-36). Greenwich, CT: Information Age Publishing.

Anderson, J., \& Erickson, J. (2003). Service-learning in teacher education. Academic Exchange Quarterly, 7(2), 111-115.

Anderson, R., Greene, M., \& Loewen, P. (1998). Relationships among teachers' and students' thinking skills, sense of efficacy, and student achievement. Alberta Journal of Educational Research, 34(2), 148-165.

Archer, W., \& Davison, J. (2008). Graduate employability. The Council for Industry and Higher Education. Retrieved from http://www.empscompacts.org.uk/resources/ LincsandRutland/Grademployability.pdf

Armor, D., Conroy-Oseguera, P., Cox, M., King, N., McDonnell, L., Pascal, A., Pauly, E., \& Zellman, G. (1976). Analysis of the school preferred reading programs in selected Los 
Angeles minority schools (Rep. No. R-2007-LAUSD). Santa Monica, CA: RAND. (ERIC Document Reproduction Service No. 130 243.)

Ashton, P. (1984). Teacher efficacy: A motivational paradigm for effective teacher education. Journal of Teacher Education, 35(5), 28-32. Retrieved from http://jte.sagepub.com/content/35/5/28.short

Bailey, J. (1999). Academics' motivation and self-efficacy for teaching and research. Higher Education Research and Development, 18(3), 343-359. Retrieved from http://www.tandfonline.com/doi/abs/10.1080/0729436990180305\#.U-QZ7_ldXmQ

Bain, K. (2004). What the best college teachers do. Cambridge, MA: Harvard University Press.

Baldwin, S., Buchanan, A., \& Rudisill, M. (2007). What teacher candidates learned about diversity, social justice, and themselves from service-learning experiences. Journal of Teacher Education 58(4), 315-327. Retrieved from http://jte.sagepub.com/content/58/4/315.short

Bandura, A. (1977). Self-efficacy: Toward a unifying theory of behavioral change. Psychological Review, 84, 191-215. Retrieved from http://psycnet.apa.org/journals/rev/84/2/191/

Bandura, A. (1986). Social foundations of thought and action: A social cognitive theory. Englewood Cliffs, NJ: Prentice-Hall.

Bandura, A. (2001). Social cognitive theory: An agentic perspective. Annual Review of Psychology 52(1), 1-26. Retrieved from http://www.annualreviews.org/doi/pdf/10.1146/annurev.psych.52.1.1

Barclay, E. F., Cross, K. P., \& Major, C. H. (2005). Collaborative learning techniques: A handbook for college faculty. San Francisco, CA: Jossey-Bass.

Barnes, L. B., Christensen, C. R., \& Hansen, A. J. (1994). Teaching and the case method: Text, cases, and readings. ( $3^{\text {rd }}$ ed.). Boston, MA: Harvard Business School Press.

Bean, J. C. (2011). Engaging ideas: The professor's guide to integrating writing critical thinking and active-learning in the classroom ( $2^{\text {nd }}$ ed.). San Francisco, CA: Jossey-Bass.

Blackburn, R. T., Pellino, G. R., Boberg, A., \& O’Connell, C. (1980). Are instruction improvement programs off target? Current Issues in Higher Education, 2(1), 32-48.

Brookfield, S. D. (1987). Developing critical thinkers: Challenging adults to explore alternative ways of thinking and acting. San Francisco, CA: Jossey-Bass.

Butin, D. (2003). Of what use is it? Multiple conceptualizations of service learning within education. The Teachers College Record, 105(9), 1674-1692.

Chickering, A. W., \& Gamson, Z. F. (1991). Seven principles for good practice in undergraduate education. The Wingspread Journal, 9(2), 3-7. Retrieved from http://onlinelibrary.wiley.com/doi/10.1002/tl.37219914708/abstract

Cone, N. (2009). A bridge to developing efficacious science teachers of all students: Community-based service-learning supplemented with explicit discussions and activities about diversity. Journal of Science Teacher Education, 20, 365-383.

Creswell, J. W. (2013). Research design: Qualitative, quantitative, and mixed methods approaches. Los Angeles: Sage Publications. Retrieved from http://isites.harvard.edu/fs/ docs/icb.topic1334586.files/2003_Creswell_A\%20Framework\%20for\%20Design.pdf

Crow, M. L., \& Pant, M. (2015). Twenty-six years of changes in education students' attitudes. Unpublished manuscript.

Darling-Hammond, L. (2000). Teacher quality and student achievement: A review of state policy evidence. Education Policy Analysis Archives, 8(1), 1-44. 
Darling-Hammond, L. (2010). Teacher education and the American future. Journal of Teacher Education, 61(2), 35-47.

Denzine, G., Cooney, J., \& McKenzie, R. (2005). Confirmatory factor analysis of the Teacher Efficacy Scale for prospective teachers. British Journal of Educational Psychology, 75, 689-708. Retrieved from http://onlinelibrary.wiley.com/doi/10.1348/000709905X37253/ abstract?deniedAccessCustomisedMessage $=$ \&userIsAuthenticated $=$ false

Dewey, J. (1944). Democracy and education: An introduction to the philosophy of education. New York: Free Press/ London: Collier-Macmillan. (Original work published in 1916). Retrieved from http:/www.stephenhicks.org/wp-content/uploads/2011/09/dewey johnpoe.pdf

Furco, A. (2001). Advancing service-learning at research universities. New Directions for Higher Education, 114, 67-78. Retrieved from http://onlinelibrary.wiley.com/doi/10.1002/he.15/abstract

Furco, A., \& Ammon, M. (2000). Service-learning in California's teacher education programs. Berkeley, CA: University of California.

Ghaith, G., \& Yaghi, H. (1997). Relationships among experience, teacher efficacy, and attitudes toward the implication of instructional innovation. Teaching and Teacher Education, 13, 451-458. Retrieved from http://www.sciencedirect.com/science/article/pii/S0742051X96000455

Guskey, T. R., \& Passaro, P. D. (1994). Teacher efficacy: A study of construct dimensions. American Educational Research Journal, 31(3), 627-643.

Henson, R. (2001). The effects of participation in teacher research on teacher efficacy. Teaching and Teacher Education, 17, 819-836.

Henson, R., Kogan, L., \& Vacha-Haase, T. (2001). A reliability generalization study of the teacher efficacy scale and related instruments. Educational and Psychological Measurement, 61(3), 404-420. Retrieved from http://epm.sagepub.com/content/61/3/404.short

Honan, J. P., \& Rule, C. S. (2002). Using cases in higher education: A guide for faculty and administrators. San Francisco: Jossey-Bass.

Hondagneu-Sotelo, P., \& Raskoff, S. (1994). Community service-learning: Promises and problems. Teaching Sociology, 22(3), 248-254.

Hoy, A. W., \& Spero, R. B. (2005). Changes in teacher efficacy during the early years of teaching: A comparison of four measures. Teaching and Teacher Education, 21(4), 343356.

Huang, G. H. (2006). Fostering active-learning in a teacher preparation program. Education, 127(1), 31-38.

Kirtman, L. (2008). Preservice teachers and mathematics: The impact of service-learning on teacher preparation. School Science and Math, 108(3), 94-102.

Lincoln, Y. S., \& Guba, E. G. (1985). Naturalistic inquiry. Beverly Hills, CA: Sage.

Luszczynska, A., \& Schwarzer, R. (2005). Social cognitive theory. In M. Conner \& P. Norman (Eds.), Predicting health behavior ( $2^{\text {nd }}$ ed., pp. 127-169). Buckingham, England: Open University Press.

McEachern, R. W. (2001). Problems in service learning and technical/professional writing: Incorporating the perspective of nonprofit management. Technical Communication Quarterly, 10(2), 211-224. 
Mezirow, J. (2000). Learning as transformation: Critical perspectives on a theory in progress. San Francisco, CA: Jossey-Bass. Retrieved from http://library.wur.nl/WebQuery/clc/1745756

Mitchell, R. C. (2004). Combining cases and computer simulations in strategic management courses. Journal of Education for Business, 79(4), 198-204. Retrieved from http://www.tandfonline.com/doi/abs/10.3200/JOEB.79.4.198-204\#.U-QNTPldXmQ

Moore, K. D. (2014). Effective instructional strategies: From theory to practice. Thousand Oaks, CA: Sage Publications.

National Research Council (2012). Education for life and work: Developing transferable knowledge and skills in the $21^{\text {st }}$ century. Washington DC: National Academies Press.

Nelson, L. P., McMahon, S., \& Torres, T. (2012). The impact of a junior high school community intervention project: Moving beyond the testing juggernaut and into a community of creative learners. School Community Journal, 22(1), 125-144.

Nelson, L. P., Tice, K. C., \& Theriot, S. (2008). Impact of service-learning on teachers' efficacy. Academic Exchange Quarterly, 12(3), 102-107.

Panek, R. (2005, January 16). 101 redefined: Colleges rethink the large lecture course. New York Times. Retrieved from http://www.nytimes.com/2005/01/16/education/edlife/101redefined.html? $\mathrm{r}=0$

Paul, R., \& Elder, L. (2009). Miniature guide to critical thinking concepts and tools. $\left(6^{\text {th }}\right.$ ed.). Dillon Beach, CA: Foundation for Critical Thinking.

Potthoff, D., Dinsmore, J., Stirtz, G., Walsh, T., Ziebarth, J., \& Eifler, K. (2000). Preparing for democracy and diversity: The impact of a community-based field experience on preservice teachers' knowledge, skills, and attitudes. Action in Teacher Education, 22(1), 79-92.

Root, S., Callahan, J. \& Sepanski, J. (2002). Building teaching dispositions and service-learning practice: A multi-site study. Michigan Journal of Community Service Learning, 8(2), 5060.

Rushton, S. P. (2000). Student teacher efficacy in inner-city schools. The Urban Review, 32(4) 365-383. Retrieved from http://link.springer.com/article/10.1023/A:1026459809392\#page-1

Scott, S. (2003). Innovative use of teaching repertoire: A study in transfer of complex strategies into classroom practice by novice teachers. European Journal of Teacher Education, $26(3)$ 365-377.

Schwarzer, R., \& Hallum, S. (2008). Perceived teacher self-efficacy as a predictor of job stress and burnout: Mediation analyses. Applied Psychology, 57(s1), 152-171. Retrieved from http://onlinelibrary.wiley.com/doi/10.1111/j.1464-0597.2008.00359.x/pdf

Shahid, J., \& Thompson, D. (2001, April). Teacher efficacy: A research synthesis. Paper presented at the Annual Meeting of the American Educational Research Association, Seattle, WA. Retrieved from http://files.eric.ed.gov/fulltext/ED453170.pdf

Smith, L. W, \& Van Doren, D. C. (2004). The reality-based learning method: A simple method for keeping teaching activities relevant and effective. Journal of Marketing Education, 26(1), 66-74.

Tice, K. C., \& Nelson, L. P. (2013). Towards understanding effective community field experiences. In V. Jagla, J. Erickson, \& A. Tinkler (Eds.), Advances in service-learning: Transforming teacher education through service-learning (pp. 240-252). Charlotte, NC: Information Age Publishing. 
Tice, K. C., \& Nelson, L. P. (2015). Promises and pitfalls of service-learning in teacher preparation: Lessons from longitudinal research. In V. Jagla, A. Furco, \& J. Strait (Eds.), Service-learning pedagogy: How does it measure up? Charlotte, NC: Information Age Publishing.

Todd, R., \& Brinkman, S. (2008). Service learning in a social studies methods course: Experience and place-based curriculum. The Educational Forum, 72, 79-91.

Tschannen-Moran, M., \& Woolfolk-Hoy (2001). Teacher efficacy: Capturing an elusive construct. Teaching and Teacher Education, 17(7), 783-805. Retrieved from http://www.sciencedirect.com/science/article/pii/S0742051X01000361

Tschannen-Moran, M., Woolfolk-Hoy, A., \& Hoy, W. (1998). Teacher efficacy: Its meaning and measure. Review of Educational Research, 68(2), 202-248. Retrieved from http://www.sciencedirect.com/science/article/pii/S0742051X01000361

Wasserman, K. B. (2009). The role of service-learning in transforming teacher candidates' teaching of reading. Teaching and Teacher Education 25(8), 1043-1050.

Woolfolk-Hoy, A., \& Davis, H. (2006). Teacher self-efficacy and its influence on the achievement of adolescents. In F. Pajares \& T. Urdan (Eds.), Self-efficacy beliefs of adolescents (pp. 117-137). Greenwich, CT: Information Age Publishing.

Woolfolk, A., \& Hoy, W. (1990). Prospective teachers' sense of efficacy and beliefs about control. Journal of Educational Psychology, 82(1), 81-91. Retrieved from http://psycnet.apa.org/journals/edu/82/1/81/

Youngblood, N., \& Beitz, J. M. (2001). Developing critical thinking with active-learning strategies. Nurse Educator, 26(1), 39-42. Retrieved from http://journals.1ww.com/nurseeducatoronline/Abstract/2001/01000/Developing_Critical_ Thinking_with_Active_Learning.16.aspx

Zeichner, K. (2010). Rethinking the connections between campus courses and field experiences in college- and university-based teacher education. Journal of Teacher Education, 61(12), 89-99. 